\title{
Gathering around Hull-House Dining Tables
}

\section{Sarah Robbins and Carrie Helms Tippen}

Hilda Satt Polacheck, who had immigrated to America in 1893, could hardly wait to return to her former Halsted Street neighborhood to attend the fortieth-anniversary festivities for Hull-House in 1929. What drew Polacheck and so many others back to the settlement, even if, as in her case, they no longer lived in Chicago? Certainly, the personal magnet was Jane Addams. As Polacheck reported in her memoir, I Came a Stranger,

Jane Addams moved among the great and the humble just as any mother would when her far-flung children returned to the old home for a reunion. She knew everybody's name. She asked after children of the former children who had come to Hull-House years ago as bewildered, uprooted little immigrants. . . . I felt that all the people who had come to that reunion were her family. ${ }^{1}$

For Polacheck, writing about this occasion years later, the anniversary dinner presented the central image affirming this feeling of domestic community: "I will never forget how [Addams] seated me at her table in the dining room. I know that many celebrities sat around that table that night, but I only remember Jane Addams at the head of the table, carving a roast, as if she were serving a family."2 Polacheck's recollections were unabashedly romanticized, but this 
episode in her memoir positions shared foodways at the heart of the settlement's identity. Addams, too, returns often to food in her own memoir, Twenty Years at Hull-House, both as a symbol to represent the work of the settlement and as a literal intervention tool for solving problems such as hunger, nutrition, and labor in the lives of immigrant women, children, and families living nearby. Indeed, while still a student at Rockford College, years before cofounding HullHouse with Ellen Gates Starr, Addams was already using the "breadgivers" metaphor to envision women's positively gendered social leadership, including in a commencement address invoking that analogy to frame her entire talk. ${ }^{3}$ Starting with a portrait of her father as a miller, the memoir repeatedly references bread, bread making, and bread sharing.

Idealized memories like Polacheck's and Addams's own descriptions of Hull-House programs through "food giving" language certainly offer one appealing window into settlement aspirations, but they form only a part of the picture of actual foodways at Hull-House. Settlement archives record a host of daily food-centered and food-supported activities from cooking classes to club meeting refreshments. While Polacheck's memoir places Addams at the head of the table in her role as Hull-House leader, the archival materials such as scrapbook clippings, yearbook stories, bulletin accounts, and photographs show that settlement residents and immigrant neighbors, over time, increasingly shared authority over food instruction and food-supported programming. Neither of the women's memoirs focuses primarily on food, but when read in the context of the Hull-House archive, their food-centered scenes take on additional significance, pointing to a purposeful food culture at the settlement.

Numerous scholars have already cast Hull-House as a cultural contact zone where encounters across divisions of class, gender, race, ethnicity, and belief were strategically engineered as a part of the institutional mission and practice, seeking to balance impulses of assimilation with diversity. Though longstanding critiques of the settlement's social hierarchies continue to remind us that such Progressive Era endeavors were never fully egalitarian, ${ }^{4}$ recent work by public historians at the Jane Addams Hull-House Museum (JAHHM) and in more traditional scholarly print publications have sought to balance critique of the settlement's shortcomings with updated recognition of its most democratic impulses and its (proto)feminist tendencies. ${ }^{5}$ When we bring food studies scholarship into this scholarly conversation, we gain a useful lens for highlighting the complexities of social relations at the settlement, especially those between the privileged, college-educated, white women residents and their immigrant women counterparts from a range of ethnic backgrounds. Sharing food is especially interesting as a social ritual that often aspires to equality by bringing diverse individuals into a common bonding experience with room for all at the (literal and symbolic) table. Yet, the metaphor of "the Table" also connotes a fraught social space where inequities and exclusions are brought into relief. The ability of food rituals to bind and to divide (sometimes simultaneously) makes food practice an appropriate site to examine critically how the settlement's 


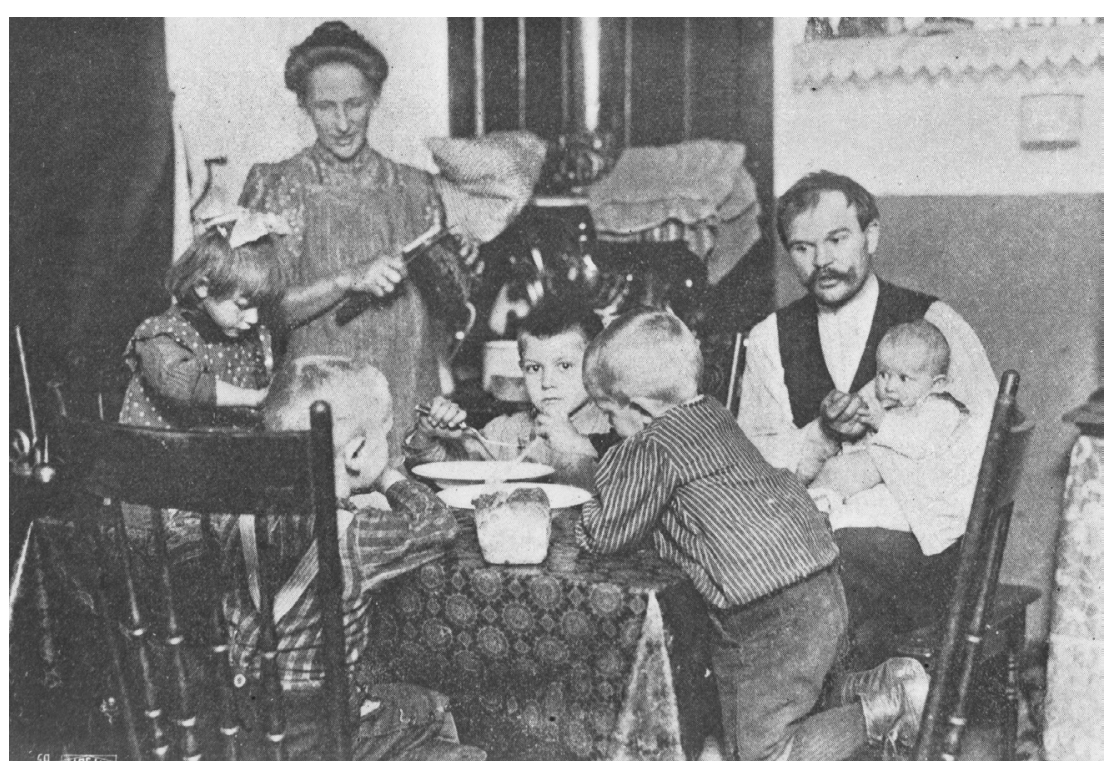

Figure 1: A family from the Hull-House neighborhood at table. Domestic Science and the Settlement Movement both aimed at solving food insecurity for the urban poor and working classes, but differed on the value of ethnic food traditions. Citation: Hull House-Neighborhood and People-Interiors, undated. Hull-House Photograph Collection, JAMC_0000_0219_0311, Special Collections and University Archives, University of Illinois at Chicago.

pedagogical vision intersected with its lived experience in cross-cultural encounters. If Hull-House's food practices were not always as egalitarian as suggested by Polacheck's nostalgic sketch, what could be called a food-supported settlement pedagogy did progress, over the decades of Addams's leadership, from a philanthropic stance, dispensing safe and nutritious food and information, toward an increasing intercultural reciprocity, sharing responsibility for creating and distributing culinary knowledge in community.

\section{Negotiating Pressures of Assimilation and Distinction with Food}

Our analysis here will track shifts in the settlement's food pedagogy that are illustrated empirically in the archive by curricular content and associated discourse's move away from programs like the New England Kitchen (NEK), as we will explain below. But we also draw on current theoretical frameworks for studying food practices as ideological and paradoxical. Thus, even as we recognize Hull-House's many successes in bridging cultures through food-centered activism, as Polacheck feels so powerfully at that reunion dinner when she eats 
a freshly carved roast while sitting alongside "celebrities," we acknowledge the limits of that commensality. As Lisa Heldke, a scholar of philosophy and food, argues, "Food may be a wonderful way to begin creating a connection between Us and Them - but no such connection is instantaneous, and even the flexible, interactive, welcoming medium of food cannot make it so." ${ }^{\prime \prime}$ Eating together is not enough to build a community; people have the agency in these exchanges, so careful attention and deliberate action are required for positive outcomes. The archive shows evidence of such attention and deliberation in food-centered activities, and the other activities of the settlement, from the Labor Museum to the Hull-House Players, support and extend the connections begun at the table. Shared meals alone are not evidence of successful community building. While shared meals have the potential to minimize differences, food practices are also important rituals in building individual identity and distinction. Sociologists Josée Johnston and Shyon Baumann suggest that contemporary foodies embrace "political dimensions of food practice" whereby eaters can use their tastes and consumer power to claim positive citizenship. Simultaneously, however, their analysis shows that foodies can use the same activities for exclusionary purposes, to "draw the boundaries between worthy and unworthy culture."7 The same activity - choosing what to eat - can have complex meanings in life and in literature, far more complex than the seemingly straightforward metaphor of "the Table" and the platitudes of "breaking bread" would suggest.

While performances around food sharing can foster a strong sense of community, we should not overstate food's ability to erase divisions. As food studies scholar and sociologist Alice Julier explains, a shared meal is "paradoxically" an "individual material act of consumption" and "part of a much larger pattern of sociable events." " To eat together can promote community, but the concrete and literal acts of biting, chewing, and digesting are strictly individual. There are limits to the power of commensality; what groups really share - often unequally - are experiences, rituals, and ideologies. Hierarchical distinctions remain - between who is a cultural insider and who is an outsider, who serves and who is served, who labors and who benefits from labor, who sits at the head and who sits at the foot of a table.

Let us revisit Polacheck's memory of the anniversary dinner as a case in point. While Polacheck reports feeling like family at the anniversary meal, rituals of distinction like carving the meat designate Addams as hostess, separate from her guests even as they are welcomed into community. As anthropologist E.N. Anderson observes, acts of eating are simultaneously acts of solidarity and separation. ${ }^{9}$ Food rituals can build intimacy within a community, but those same rituals separate that unique community from others. Though the feelings of solidarity and separation may last only for the space of a meal, there are consequences to social and cultural identities when individuals move between, within, and across food communities. Those consequences are especially relevant for the immigrant neighbors at Hull-House who faced the challenge of negotiating pressures between embracing assimilation and affirming cultural 
distinctiveness. In Hull-House activities, neighbors are asked to identify at various times with their ethnic communities, the multiethnic community of HullHouse, and the dominant middle-class, white community that called for their assimilation into white-dominated American culture. Even within the most diversity-welcoming contexts of Hull-House foodways, when ethnic differences were affirmed in such cultural markers as a cooking class specifically designated for "Italian girls only,"10 there were forces simultaneously calling for participants to assimilate within the overriding culture represented by the white, well-to-do residents. To join that very cooking class, for instance, one needed to pay an enrollment fee, however modest, and follow a curriculum situated within an education program controlled by Anglo-American collegeeducated women.

Jane Addams and the Hull-House residents of her own social class navigated this tension, too. They recognized that neighbors could benefit materially from the cultural capital garnered through knowledge of "American" culture, including WASP foodways. But they increasingly realized that the traditional knowledge and social accomplishments of immigrant communities - including culinary ones - were valuable and worth preservation. Therefore, Addams and her resident colleagues embraced learning they themselves gained from the cultural resources of their neighbors, whether through a Hull-House theatre performance of Greek drama or through the political acumen working-class organizers brought to labor issues. So too, food-centered activities of Hull-House eventually provided all community members with interactive opportunities to reconfigure their individual and group identities through a community-building pedagogy of shared authority around food practices. Thus, both the individual self-fashioning of Addams and Polacheck around Hull-House foodways and the more collaborative, if admittedly sometimes vexed, process of communal self-definition for the settlement enacted a shared enterprise seeking democratic expression at dining tables.

Understanding that the entanglements of shared food practices are further knotted by the unique tensions and identity negotiations at Hull-House, our portrait of food practices there identifies complications in cross-cultural food encounters to illustrate that food, in itself, does not create meaningful social relationships by its mere presence. Rather, writings by community members like Polacheck and Addams herself highlight Hull-House settlement leaders' growing attention to multifaceted identity differences and to building sustained cross-cultural relationships through food encounters. Specifically, as Addams's views on collaborative pedagogy developed, the role of settlement food changed accordingly. Spaces for food production and consumption shifted along with food-related approaches for promoting sociability, solidarity, and political agency across class and ethnic borders. This evolution progressed unevenly, however, and was experienced differently by different community members. To illustrate, throughout this essay we call upon remembrances from Polacheck's self-descriptions as "a Hull-House Girl” (according to her 
book's subtitle) to supplement more official records in the archive, including texts crafted by Addams herself. Using this dialogic approach highlights the recurring tensions between aspirational ideals of democratic hospitality that resisted assimilation and the limits inherent in any culture-making enterprise. Nonetheless, encouraged by French philosopher Michel de Certeau's suggestions for claiming agency within constrained spaces, we aim to recover positive aspects of Hull-House's foodways-based learning legacies. ${ }^{11}$ Rather than seeing food memories recorded in memoir texts as sentimental or "mere" nostalgia, on the one hand, or viewing settlement foodways as hopelessly caught up in misguided, upper-middle-class do-gooder moves to acculturate immigrants, on the other, we instead aim here for a more complex interpretation of Hull-House foodways. ${ }^{12}$ The triangulation of memory writing by Polacheck and Addams with contemporary newspaper accounts and artifacts from the settlement's own records of teaching and social programs allows us to generate a more nuanced and polyvocal history of foodways at Hull-House.

\section{Welcoming Immigrants}

Hilda Satt Polacheck (at that point Hilda Satt, before her marriage) started participating in Hull-House activities in 1900 - an ideal time to affiliate with the settlement. Founded in 1889, Hull-House, by the dawn of the new century, had already extended its physical footprint through ambitious construction projects and had greatly expanded its programming for (and with) immigrant neighbors. A suburb when Charles Hull had built his home in the 1850s, the neighborhood was fully urbanized by the time Hull-House became a settlement. Addams would make the project famous as a quintessentially American enterprise through magazine articles, books like Twenty Years at Hull-House, and speeches all over the world.

Hull-House's expansion in the new century included refining its clubs and classes content in line with the maturing vision of its cofounders, Addams and Ellen Gates Starr. Following the lead of the Toynbee Hall London settlement that had inspired Addams in the first place, Hull-House did initially take a hierarchical, philanthropic approach. Yet, from the start, Addams would emphasize distinctions between that English settlement and her more collaborative, reciprocal goals. As early as 1893, in two essays for Philanthropy and Social Progress, Addams acknowledged the "humanitarian" aims of Hull-House but also insisted, in her "Subjective Necessity" chapter, that the American settlement was providing at least as many benefits to the college-educated "residents" as to the neighborhood's immigrants. Likewise, in the companion essay, "The Objective Value of a Social Settlement," she stressed that immigrants coming to Hull-House did so for "social intercourse" more than charity. ${ }^{13}$

Hull-House also worked to build bridges between diverse ethnic communities, connecting immigrants who otherwise would have been unlikely to come together, as Polacheck would note on her first visit, for an evening party. 
She was stunned to find attendees "from Russia, Poland, Italy, Germany, Ireland, England, and many other lands," and even more surprised to find "no one seemed to care where they had come from, or what religion they professed, or what clothes they wore, or what they thought." Indeed, by the time Polacheck joined the settlement's programs, Hull-House was a veritable microcosm of diversity. As bulletins and yearbooks now held in the Hull-House Collection at the University of Illinois at Chicago, attest, clubs and classes pitched to multiple niche audiences of ethnic groups were complemented by broader community-building resources such as guest speakers, theatre performances, and social services ranging from a kindergarten to a public bathhouse. No wonder Polacheck reports that she "spent most of [her] evenings" there for over a decade. ${ }^{14}$

\section{Kitchen as Site of Assimilation}

The evolution of Hull-House's food-based programming was far from linear, instead progressing unevenly toward a democratic vision that, her Twenty Years memoir aside, was never fully achieved in Addams's lifetime. Nonetheless, we can point to milestones evident in the memoirs under review here, as well as in the foodways-related archive, that demonstrate aspirations to find a balance between acculturation and cultural distinctiveness. One of those turning points involved the partial rejection of what had been eager adoption of the NEK movement's dictates. In the shift between Addams's original enthusiasm over the NEK and her settlement's purposeful reconfiguration of its practices, we find a parallel to the broader evolution of Hull-House pedagogy from benevolent, hierarchical engagement with immigrant neighbors to more collaborative relations.

Addams's shifts in attitude toward the NEK model, as we will outline in more detail below, developed within the context of a maturing pedagogy at the settlement. Though race and ethnicity are categories central to intercultural work, in this case gender and social class were also crucial factors. ${ }^{15}$ Gender roles shaped both the early tendency of Addams's settlement toward a domestically inflected benevolence and its shift toward reciprocal learning. Hull-House, as an adaptation of London's Toynbee Hall, was in a poor urban neighborhood where most college-educated city dwellers would have hesitated to "settle." Gender differences between the two settlements, though, promoted differing pedagogical practices. ${ }^{16}$ Toynbee's residents (with the exception of Canon Samuel Barnett's wife Henrietta) were college men. In contrast, Hull-House was populated primarily by college-educated women who lived cooperatively there and sought to support the working-class neighborhood by teaching classes, making art and literary culture available, and providing opportunities for social activities. Hull-House's gendered identity organically shaped its social justice projects - from opening a kindergarten to founding Chicago's first outdoor playground to addressing challenges to urban food health and safety. Methodologically, though Addams and her colleagues moved relatively quickly to adopt research-based program development consistent with prompts from their Toynbee mentors, ${ }^{17}$ the American 


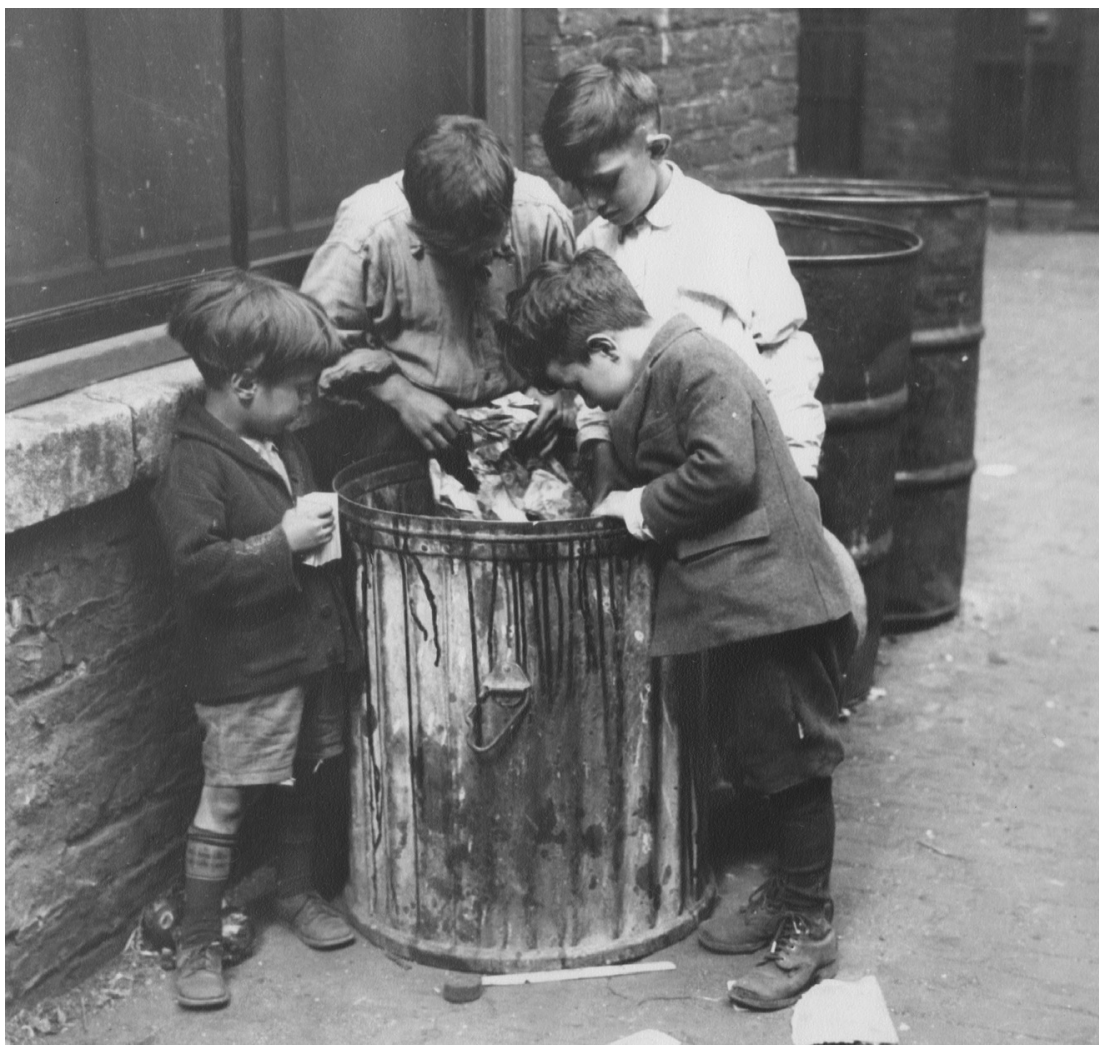

Figure 2: Neighborhood children scavenging food. Food insecurity and safety remained one of Hull-House's enduring concerns. Citation: Hull House-Children, undated. Hull-House Photograph Collection, JAMC_0000_0096_0114, Special Collections and University Archives, University of Illinois at Chicago.

settlement's residents being mainly women encouraged them to blend hard datagathering strategies drawn from the new social sciences with practices grounded in womanly traditions of community service.

Consistently, Addams's bestselling Twenty Years memoir situated the foodways within the gendered pedagogy of Hull-House. In that text and in other reports on her cultural work, Addams continued to draw on and to extend the "breadgivers" metaphor that she and her classmates at Rockford College had embraced as emblematic of their hopes for enacting women's social leadership. ${ }^{18}$ Along those lines, Addams depicted herself as discovering her mission for HullHouse's founding from observing the hungry poor of London's East End.

[W]e saw two huge masses of ill-clad people clamoring around two hucksters' carts. They were bidding their far- 
things and ha'pennies for a vegetable held up by the auctioneer, which he at last scornfully flung, with a gibe for its cheapness, to the successful bidder ... [who] had bidden in a cabbage, and when it struck his hand, he instantly sat down on the curb, tore it with his teeth, and hastily devoured it, unwashed and uncooked as it was. ${ }^{19}$

Addams's portrait of the starving man signaled both a figurative and a literal commitment that the Chicago settlement would make to the immigrant poor, offering food — intellectual and spiritual — as well as addressing other basic physical needs. Her recurring use of food tropes throughout the memoir also indicated that these needs were, in fact, interrelated. Furthermore, this language branded the settlement's efforts to feed-and "feed"-its neighbors as gendered, linked to expectations for middle-class women's social leadership. This was a pragmatic strategy using cooking as a means of enhancing the lived experiences of various city dwellers. The tradition of women reformers focusing on the kitchen as a rightful domain of influence was already well established by Addams's day, with forerunners such as Catharine Beecher and Harriet Beecher Stowe's advice books having planted a womanly flag for leadership there. ${ }^{20} \mathrm{Ad}$ dams and her colleagues embraced this sanctioned role to further their cause.

Significantly, though, they adjusted strategies as they learned more about their neighbors. Addams's self-critical assessment of her food-related teaching illustrates the responsive nature of Hull-House community education for and with immigrants. For instance, Addams looked back in Twenty Years on two efforts to intervene in problematic food practices in the neighborhood - the NEK and the Coffee House-and drew pointed distinctions between them. Although both arose from a pattern that would continue throughout Addams's settlement leadership — beginning with study of a problem and moving to experimenting with how to address it-her contrasting descriptions of these two ventures underscore how a growing appreciation of immigrant neighbors' own foodways changed the settlement's food-based strategies.

The NEK emerged within the larger culture of the home economics movement that had been launched by Catharine Beecher and her sister Harriet Beecher Stowe in such writings on enlightened housekeeping as The American Woman's Home (1869). ${ }^{21}$ As former JAHHM director Lisa Lee has pointed out, major leaders in the NEK enterprise, including Ellen Swallow Richards and Mary Hinman Abel, began in the late 1880s in Boston to promote a scientific approach to food preparation, nutrition, and sanitation. Richards was a collegeeducated chemist with a Vassar degree who carried out careful studies of water quality in Massachusetts, introduced the term “ecology" into Americans' vocabulary, and published a number of books promoting scientific approaches to cooking. ${ }^{22}$ Addams reports in Twenty Years that a Hull-House representative was sent to Boston "for a training under Mrs. Richards" in order to establish a public kitchen on that model at the settlement. ${ }^{23}$ As Lee further explains, how- 
ever, Addams and her colleagues realized before long that a rigid application of the NEK model was not in tune with Hull-House's inclusive ethos. ${ }^{24}$

The NEK, Addams explained in Twenty Years, did address a serious food issue facing the urban neighborhood: food safety. It was this dimension of the NEK agenda that most drew Addams and her resident colleagues to the NEK framework. Two Hull-House residents were tasked by the USDA and the Department of Labor to study Chicago immigrants' diets. This research revealed that women living in the neighborhood were paid so little and worked such long hours that they could not afford the time or the expense required to cook nutritious family meals. Instead, they often "bought from the nearest grocery the canned goods that could be most quickly heated, or gave a few pennies to the children with which they might secure a lunch from a neighboring candy shop." ${ }^{25}$ Accordingly, as one contemporary newspaper reported, opening the NEK in August 1893 represented a potentially worthy step in gendered "philanthropy"-more "good work being done among the working people of the West Side by the ladies of Hull House," with the "ladies" term in this published feature story a significant class marker. ${ }^{26}$

As additional newspaper accounts of the public kitchen emphasized, Chicago social leaders viewed this new settlement project as an enlightened blend of philanthropy with science: "Hull-House Kitchen Opened: Standard Dishes Made According to Scientific Rules," one headline touted. ${ }^{27}$ Hull-House's public kitchen aimed to provide nutritious food at low cost through devices such as the Aladdin oven and simple menus of soups, roasted meats, and breads. ${ }^{28}$ Given their research, Addams and her resident colleagues imagined that the public kitchen would strategically employ "scientific training and careful supervision," teaching the poor how to save money, labor, and time while preserving the nutrient value of meats and vegetables. ${ }^{29}$

Historian Delores Hayden notes that home economics and social work "channeled the energies of many newly educated American women into the reform projects of the Progressive Era." At the forefront of these two movements in the 1890s were Richards and Addams; both aimed, Hayden suggests, to establish "collective or cooperative services" to meet the needs of the urban tenement dweller whose time and space resources were scarce. ${ }^{30}$ And, in the view of the domestic science movement, nutritious food was also key to moral living. That is, long before the emergence of an academic field focused on food practices as ideological, ${ }^{31}$ nineteenth-century domestic science leaders self-consciously positioned foodways as values oriented and thus as potential agents of social change/control. In that context, food writer Laura Schenone argues that movement leaders aimed to reform working-class women's kitchens as a step in broader social reform:

Through proper cooking, women could encourage better health and better morality. They could prevent infants from dying. ... They could prevent greedy desires in their husbands 
and sons. They could end alcoholism. They could help their families gain upward mobility, higher status, and more comfort by securing appropriate table manners and etiquette. ${ }^{32}$

Stressing the role of rhetoric in this ongoing enterprise, Elizabeth Engelhardt notes how related discourse "often vilified immigrant, ethnic, and regional foodways, in favor of a bland, northeastern, WASP-ish food tradition." 33

As contemporary press coverage of the Hull-House public kitchen's launch demonstrates, the settlement was implicated, at this stage, in the ideology that food practices had the most ameliorative impact when aligned with the dominant culture's management of the working classes. One newspaper account pasted in Addams's scrapbook shows the Hull-House cofounder herself was, initially, an enthusiastic spokesperson:

\begin{abstract}
Miss Jane Addams addressed the ladies [local social leaders at the NEK opening] at some length, using charts when she explained the methods of scientific cooking. Her remarks referring to the kitchen enterprise were substantially as follows: "It is a part of the new philanthropy to recognize that the social question is largely a question of the stomach: temperance workers are coming to feel that they cannot make headway if they ignore the importance of proper nutrition for the body, for with monotonous food is apt to go whisky to whip up the digestion. Mission workers of all kinds are coming to feel that their weak point is the commissariat." 34
\end{abstract}

If Addams's linkage of temperance goals, the NEK, and philanthropy seems surprising today, it would not have been in 1893, when leaders such as Frances Willard and Eliza Stewart advocated the elimination of alcohol to address such persistent ills as domestic abuse of women and children, as well as financial woes within families victimized by drunken husbands. However, as Addams and her resident colleagues came to know the richness of their neighborhood's diverse cultural heritages better, through a whole array of shared social practices, the settlement leaders' view of food practices shifted. In her Twenty Years memoir, when revisiting the NEK project, Addams would poke fun at her own failure to recognize how ethnic differences in taste came into play in neighbors' reactions to the NEK's original bill of fare. So, she reports, one neighborhood woman "frankly confessed, that the [public kitchen's] food was certainly nutritious," but not in line with "what she'd ruther" eat. ${ }^{35}$ In contrast to the NEK, which encouraged assimilation both to New England cuisine and to its associated moral values, Addams's Twenty Years reflections on eventual shifts in Hull-House food practices would tout the Coffee House's more varied and responsive menu and milieu. 


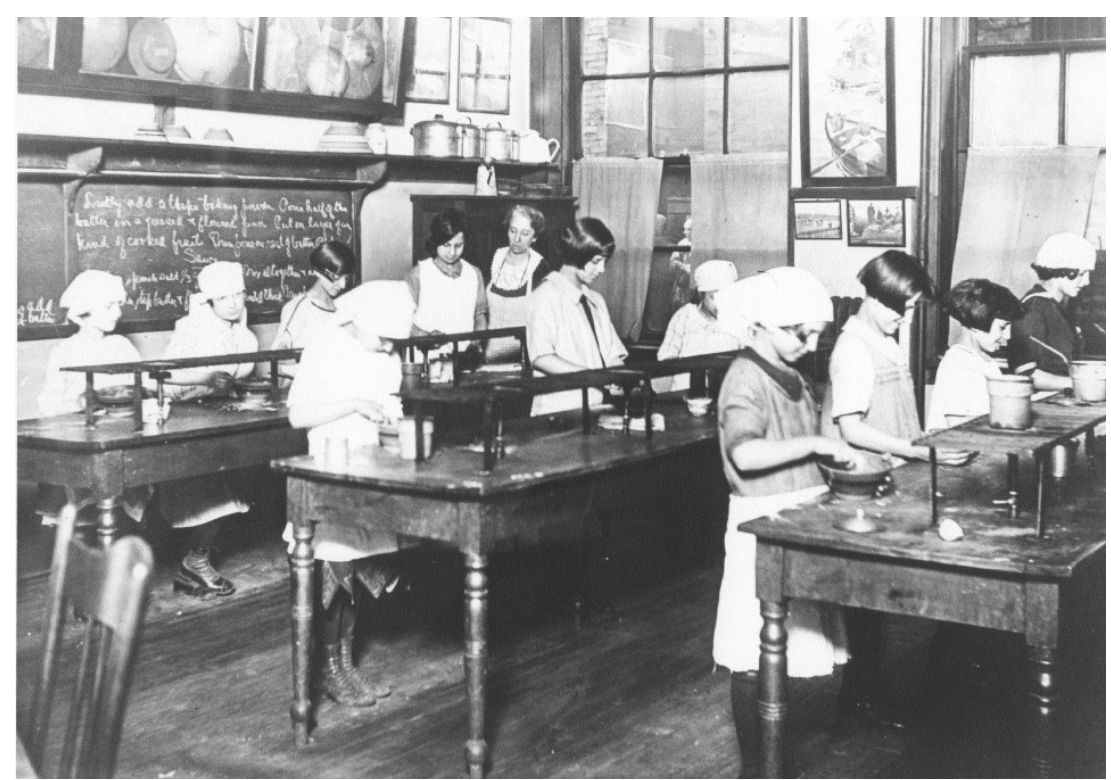

Figure 3: Young women in a cooking class. Domestic Science continued to influence cooking instruction at Hull-House, even as the work of the Coffee House moved toward more social and community-oriented goals. Citation: Hull House-Cooking Classes, undated. Hull-House Photograph Collection, JAMC_0000_0117_0140, Special Collections and University Archives, University of Illinois at Chicago.

We must read Addams's account here with awareness of rhetorical posturing, however. She regularly set up before/after and at-first-naïve/later-enlightened discursive structures in her speeches and writings to characterize a progression in thinking behind Hull-House programs. Furthermore, the settlement archive shows that the public kitchen and the Coffee House actually continued to be closely associated with each other operationally. That is, accounts appearing in the Hull-House Yearbook with only slight changes in wording over the years echoed Addams's characterization of the Coffee House as highly popular in drawing customers to its sociable in-house atmosphere, yet still reported that the meal delivery service of the NEK-aligned public kitchen continued over the years, with "every noon many orders of soup and coffee and hot meat sandwiches . . carried out into the neighboring factories." ${ }^{36}$ Meanwhile, though the Coffee House and its associated lunch-serving cafeteria diverged from the domestic science principles of the NEK, those practices remained at work elsewhere in Hull-House programming, such as some of the cooking classes.

Overall, texts in the settlement archive indicate that, however much Addams and her colleagues moved away from the NEK model, Hull-House continued to approach neighborhood foodways from a position of morality 
management. For example, even as she launched into a critique of the public kitchen as mistaken practice, Addams reasserted the settlement's resistance to alcohol consumption and its favoring of, instead, different forms of "soft drink," whether "grape juice" or "soda water." She intoned: "[S]o far as drinks were concerned[,] we never became a rival to the saloon, nor indeed did any one imagine that we were trying to do so." ${ }^{37}$ In setting this barrier against alcoholic beverages at the settlement, Addams reaffirms links between foodways practices and expressions of morality as central to the Hull-House mission. She also asserts the kind of determined management of others' social habits that has led some scholars to critique her praxis as hopelessly biased. Recognizing those limitations in her approach, particularly the confidence with which she claims the right to prohibit alcohol, requires us to note that she is withholding a valued element of meals as then enjoyed in some immigrant homes and other food-oriented establishments in the neighborhood, not just the "saloons" she references so negatively. However, her stance is also notable for its alignment with nineteenth- and early-twentieth-century views on temperance as a means of protecting women and children from the domestic abuse then associated with heavy consumption of alcohol.

\section{Safe Food as Shared Agenda}

Despite Jane Addams's Twenty Years portrayal of Hull-House as turning away from domestic science, some periodical accounts in her day-as well as reports within the settlement's in-house publications - point to ways that the "helping" stance behind the NEK project did have positive outgrowths for the neighborhood's food economics. In this regard, we should note that the pullback from the NEK focused on what to eat, not how to address such social justice issues as food safety or equitable access to healthy options. Even after discarding some of its original efforts, the public kitchen continued pragmatic interventions such as cooperative purchases of coal for cooking and of bulk food that lowered families' costs. ${ }^{38}$ One enterprise involved sales, during the summer months, of ice and milk to neighborhood consumers - a program cofacilitated by the Chicago Tribune, the Chicago Milk Commission, and the settlement. A 1904 Hull-House Bulletin article characterized this ongoing initiative, which also provided "instruction . . . as to the care of the milk after it was taken home," as especially beneficial for invalids and children and much appreciated by the neighborhood. ${ }^{39}$

Recovering the history of partnerships like the safe milk program and cooperative bulk food buying reminds us that the reluctance to embrace menus that Addams and her colleagues encountered in the original public kitchen involved factors beyond stubborn determination to avoid new foods. Historian and foodways scholar Donna Gabaccia describes the impulse of immigrant communities to resist assimilation into the dominant culture's foodways through what she calls "culinary conservatism." Gabaccia notes that culinary conservatism may 
be the result of "culinary pride" in ethnic traditions, a mandate of religion, or an attempt to capture a "feeling of mastery" over one aspect of daily life amid the turmoil of learning to live in a new country. And, she argues, resistance to new foodways may even be a necessity due to scarce financial resources. ${ }^{40}$

In that vein, even before becoming active in the Hull-House community, Polacheck and her widowed mother could have given Addams a telling example of how immigrants' culinary conservatism, as Gabaccia's research suggests, could be bound up in a complex web of factors. While desperately seeking employment in the 1890s, young Hilda Satt had few sources of solace beyond family time. Yet, the emotional support associated with home foodways was fraught with a related awareness of "food scarcity" and the need for "frugal meals." Within their constrained economic context, the Satt family favored foods from their pre-American life. Said Polacheck:

Mother would cook a wonderful meal of calf's liver, gravy, and mashed potatoes. She would cook this several times a week. I soon discovered when she bought a few pounds of meat, the butcher would give her a calf's liver free. . . . [A]t that time calf's liver was considered only fit for dogs and cats. But my wise mother had learned in Poland, long before the word "vitamins" was heard, that liver was one of the best foods. ${ }^{41}$

Polacheck's anecdote highlights several reasons why Hull-House's neighbors might choose familiar foods over NEK-type fare. Her memory situated calf's liver as an important part of the family's diet, a comforting, predictable presence, something from Poland to savor in their new US home. She further pitted the language of the domestic science movement ("vitamins") against the culinary knowledge of community ("my wise mother"). Thus, Polacheck's mother seemed to know what American butchers and domestic scientists at that time did not: calf's liver is nutritious. Yet, the working-class author also suggested that the family's economic circumstances encouraged them to rely on cheaper cuts of meat.

Nonetheless, Polacheck's pride in her mother's food ingenuity did not obscure this immigrant writer's awareness of food safety concerns facing many recent immigrants in their crowded urban neighborhoods. When she enrolled later in a writing class at Hull-House, she chose for her first assignment to address this topic - and, as Polacheck's daughter and memoir editor Dena Epstein has reported, this composition is the only one of her mother's early writings to have been saved.

Its argument shows that we should not equate immigrants' resistance to "scientific" lessons about foodways with a failure to recognize health issues. The story-entitled "The Ghetto Market" - is a full three pages long in its printed version for I Came a Stranger. The essay presents highly negative descriptions of food wares in nearby markets, beginning with an unsanitary poul- 
try shop. The composition then visits a crowded stand with fish "kept on the window sills" where the uncooked items often slip into the mud. The speaker also indignantly describes cakes drawing flies at another stall and a fruit stand where the "prunes, raisins, nuts" and more were "uncovered except for the flies." The essay closes with rhetorical questions:

Cannot the poultry shop, fish stall and cake stand be kept off the street, free from the dust and flies? Why should this class of people who work harder than any other be compelled to eat inferior food when they might be supplied with good food for the same money? Are there not plenty of men employed in building houses, ice boxes and various appliances for keeping provisions? Yet these people eat food sold on the street under the filthiest conditions. ${ }^{42}$

Lest we assume this story represented not her own views but a performance of middle-class values to please the teacher, we can point to parallel examples elsewhere in Polacheck's memoir, such as anecdotes in which she forcefully praised Addams for promoting safer food practices-including disposal of waste. Recalled the immigrant author later: "Where there were alleys in back of the houses, these alleys were filled with large wooden boxes where garbage and horse manure were dumped. In most cases these boxes did not have covers and were breeding places for flies and rats." Noting that Addams's efforts to engage the city health department in the problem proved unsuccessful at first, Polacheck commended her mentor for eventually securing appointment as "garbage inspector for the ward," a political victory securing better health for the whole neighborhood. ${ }^{43}$

For this sanitation project, and for a related study of links between a rise in typhoid cases and ineffective garbage services, Addams and Polacheck each credited the Hull-House Woman's Club, whose membership included both residents and neighbors. Thus, in "Women's Conscience and Social Amelioration," Addams described how club members divided their ward into segments and spent months gathering data to document how the city's refuse department was failing to pick up garbage. Club members juxtaposed those findings with disease reports and then used that data to campaign for enhanced sanitation service. So too, when celebrating this project's assault on food waste as a health hazard, Polacheck dubbed the cross-class, cross-ethnic Woman's Club "a real venture in democracy" by virtue of its ongoing collaborations. ${ }^{44}$

These matching assessments alert us to avoid dichotomizing middle-class and working-class views of food safety. Through their cross-class partnership, settlement women from different social groups proactively addressed shared foodoriented concerns, with their collaboration reinforced through their meetings' community-building refreshments, sometimes hosted by one of the more well-todo members, sometimes prepared by one of the settlement's cooking clubs. 


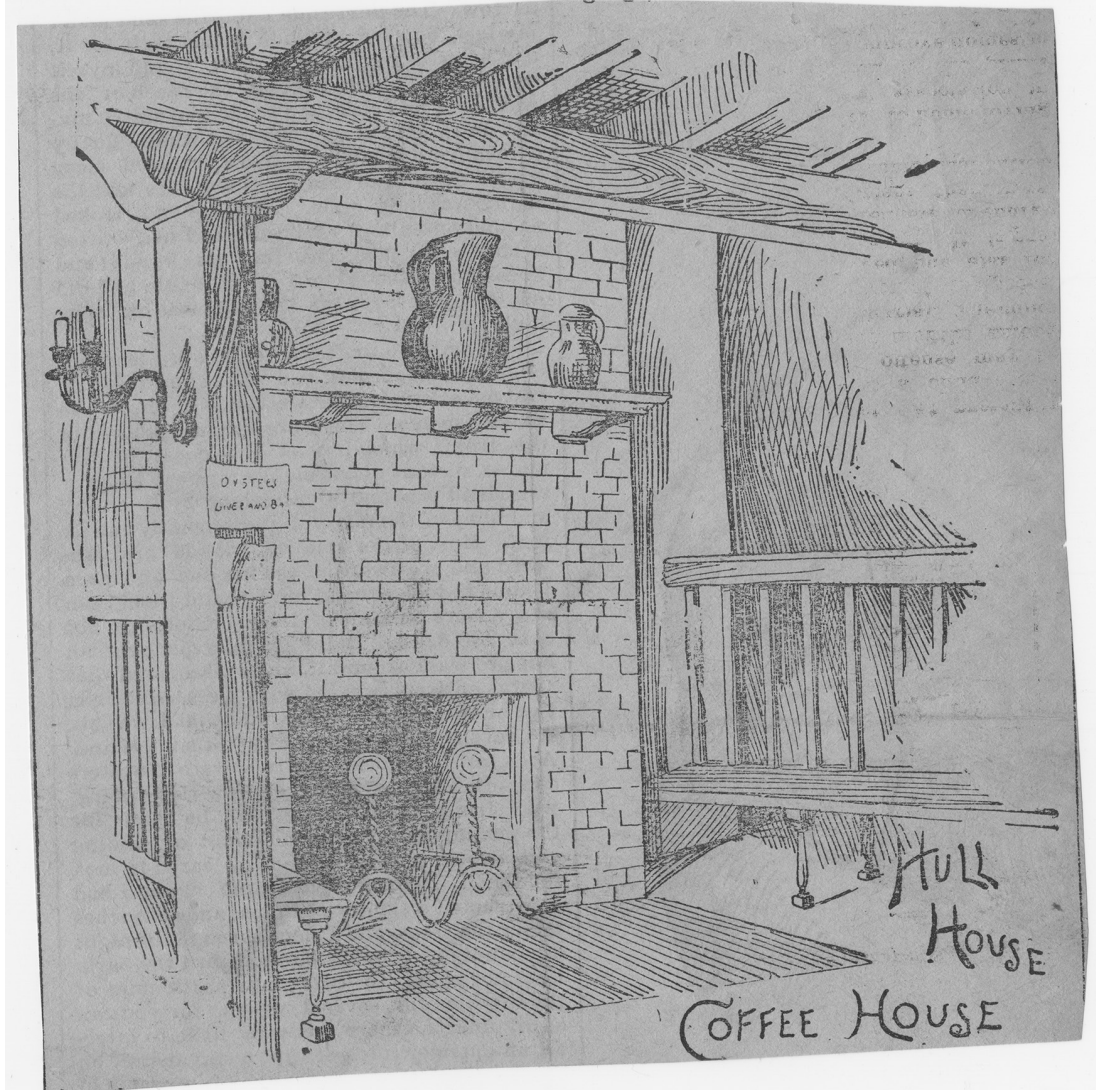

Figure 4: Artist's rendering of the Coffee House fireplace. As a welcoming social space, the Coffee House encouraged cross-class and cross-cultural encounters over food. Citation: Unsigned line drawing from a newspaper article in the Hull-House clippings scrapbook, volume 1, box 71, folder 506. Jane Addams Memorial Collection. HHC_0071_506B_P49_1.

\section{Clubs and Coffee House Community Building}

Parallel to the reading clubs that began with residents like Ellen Gates Starr teaching the literary texts they had studied in college, but which grew more open to neighborly leadership. Food-based activities at Hull-House became more reciprocal and less hierarchical, more social and less scientific, more pragmatic and less moralistic. Literary study at Hull-House metamorphosed to a more diverse local canon, including theatrics in multiple languages and aesthetic traditions; so too, shared foodways become purposefully intercultural, 
a potential site for resisting straightforward assimilation through a commitment to diversity and inclusiveness.

Similarly, the Labor Museum, founded by Addams in part to highlight and honor the knowledge of older-generation immigrants in the neighborhood, demonstrated Addams's rising commitment to cross-cultural exchange. On Saturday nights, Labor Museum hosts (who today would likely be called "community curators") presented ethnic handicrafts, including milling wheat, to blended audiences of neighbors, settlement residents, and visitors. In promoting knowledge and practices from outside middle-class Anglo-America, the Labor Museum embodied reciprocal learning. The Coffee House played a related role.

It is illuminating to contrast the Coffee House's social approach with the domestic science-based moral inculcation. At its core, domestic science was depersonalized, and Hull-House built its model of social change on personal relationships. Lisa Yun Lee, former director of the Jane Addams JAHHM, has written about the significance of Jane Addams and Ellen Gates Starr learning to appreciate ethnic foods favored by the neighbors they were inviting to settlement activities. For instance, drawing from the archive of Hull-House's grocery purchases ledger, Lee and the JAHHM staff identified residents' purchases of ingredients for Italian foods from nearby "Bragno e Mustari, importers and wholesalers" as an example of the founders seeking "common intercourse" with their neighbors" through food-based "conviviality." 45 Additionally, by accepting informal cooking lessons from Italian neighbors, Addams and Starr established a precedent for the ethnic food classes that would increasingly claim space among settlement courses. ${ }^{46}$

Reciprocal cultural exchange - not only around foodways but also across Hull-House's community education programs - increased at the settlement over time as Addams and her colleagues still affiliated their work with the new social sciences, but through a more humanistic framework. One overarching approach Hull-House used to foster collaborative learning was through clubs, where shared foodways joined with other brands of what Addams would call "the attempt to socialize democracy." ${ }^{47}$ In an 1896 letter to open the first issue of the Hull-House Bulletin - a publication advertising and documenting club activities and other events-Addams argued that the chief purpose of club life was to develop empathy, understanding, and meaningful relationships: "at a settlement each member should learn to know other characters, thoughts and feelings. It has been said that 'the cultivation of social life and manners . . . brings men together, makes them feel the need of one another, be considerate to one another, understand one another." 48 Though clubs reported to Addams on record keeping and costs, most groups were organized, led, and dues-funded by neighbors. In the archive of club activities, we see members forming sustained relationships while emphasizing reciprocal cultural exchange, including through food.

One long-running club operated at the intersection of foodways, collaborative learning, and cross-cultural relationships. The Friendly Club appears 
to have formed in 1898 as an urban gardening club, with the group cultivating plots in vacant lots at 12 th Street and 44th Avenue. ${ }^{49}$ The Friendly Club's members were interested in food from the garden to the table, and the club held food-supported social events, like the ice cream supper following the first meeting of the year in 1903, and hosted lectures on "simple agriculture," including "bees" and "the growth of flowers." ${ }^{50}$ According to a Yearbook entry from 1916, a by-then updated version of the Friendly Club appears to have given up urban gardening as a mission, focusing instead on social activities for whole families, including music, games, dancing — and dinners. The 1916 Yearbook brags that the club "attendance is always large and the membership includes twelve nationalities. In this connection, it is interesting to note that absolute harmony prevails and that the members live up to their name, The Friendly Club." ${ }^{51}$

In light of its purposeful diversity, we should examine the Club's main annual event, beginning in 1910: a turkey dinner served in the Coffee House each New Year's Eve. Whatever the rest of the meal looked like, in such a proudly multiethnic club this celebration around a signature American dish is striking. The turkey centerpiece may have acted to equalize the field, placing no one of the twelve nationalities at the center of the club's premier activity. That is, the Friendly Club may have foregrounded turkey for the same reasons that Addams and Starr learned to eat and cook macaroni, as a public declaration of solidarity. Additionally, Club members may have seen this menu as a way of declaring hyphenated selves, maintaining an ethnic affiliation while also adopting an American one. Through foodways, these Hull-House neighbors struck a balance between forming a new community and safeguarding their original ones.

Similarly, Hilda Satt Polacheck's description of her own leadership of the Ariadne Club underscored links between collaborative learning-bound up with intellectual and cultural uplift - and food-supported social experiences that strengthened community. For Polacheck, both elements in the Ariadne Club were crucial. Her memoir enthusiastically catalogues books that club members selected to read, including David Copperfield, Ivanhoe, and Uncle Tom's Cabin - which she deemed particularly memorable not only for introducing members to American blacks' painful historical experiences but also, indirectly, for raising questions within the group about "racial hatreds in Poland, Germany, and Russia." Alongside these studious occasions, meanwhile, the club was equally committed to being "an outlet for recreation" for its youthful members. ${ }^{52}$

According to Addams's Twenty Years best seller and the Hull-House Bulletin and Yearbook, the social needs of groups like the Ariadne Club were reliably addressed through the ever-welcoming Coffee House. In both the clubs and the Coffee House, the settlement fostered a flexible cross-cultural environment, where shared growth of many kinds became possible for both individual patrons and larger groups. Thus, the 1906-1907 Yearbook reported on the Coffee House's regular convening of customers from diverse backgrounds: 


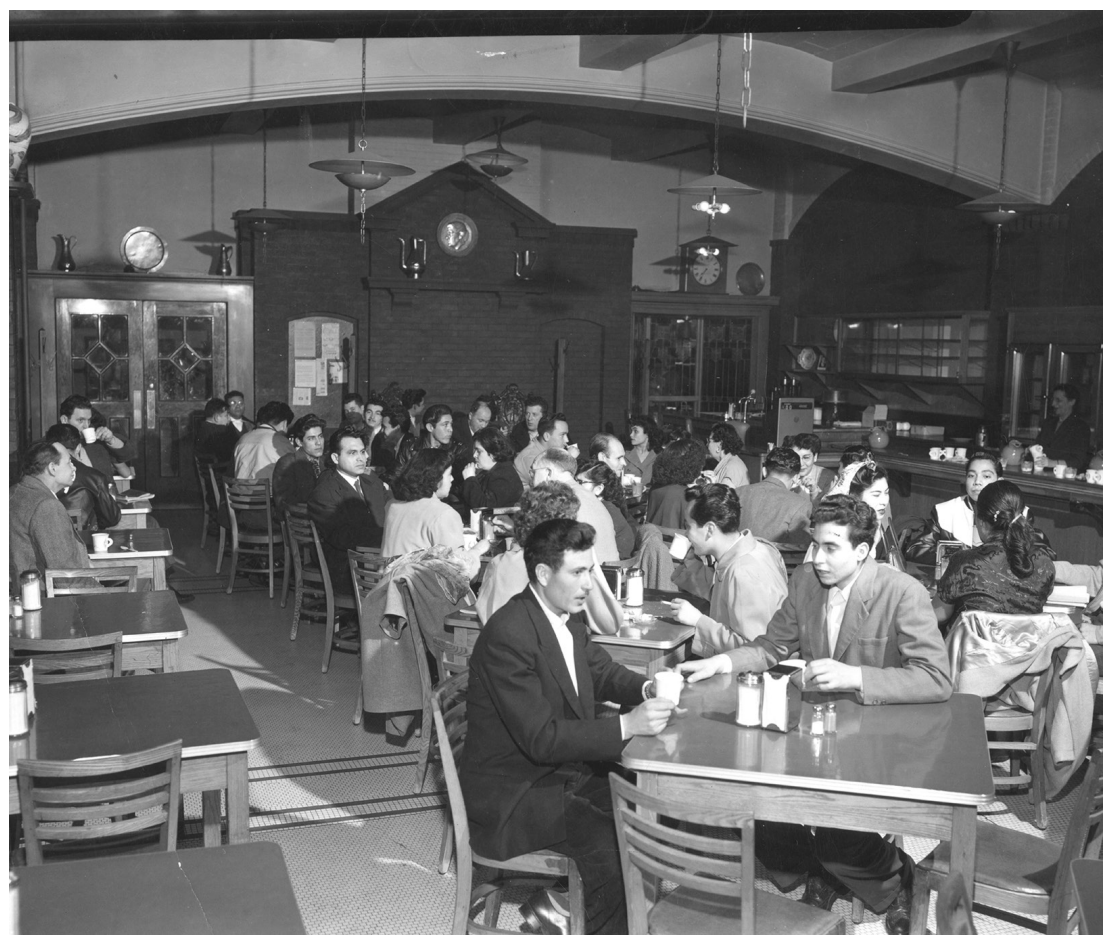

Figure 5: A scene from the Coffee House. This public restaurant space played an important role in the social life of Hull-House residents and neighbors. Citation: Hull House-Coffee Shop, undated. Hull-House Photograph Collection, JAMC_0000_0115_2517, Special Collections and University Archives, University of Illinois at Chicago.

Business men from the adjacent factories and schoolteachers from the nearest public schools use it constantly. Every evening students and Club members meet together in little groups or hold their reunions and social banquets there, as organizations from all parts of the town occasionally do. The Chicago Ethical Society hold their monthly banquets and meetings in the Coffee House, and various alumni associations and professional organizations find it a convenient place for meeting. It is used constantly by the social clubs in connection with their party refreshments and banquets and it is also a great convenience to the residents of Hull-House, the directors of clubs and teachers of evening classes. ${ }^{53}$

Whereas the NEK attempted to solve problems of nutrition through a topdown model of assimilation to scientific American foodways, the Coffee House 
promoted cross-cultural exchange with ethnic food preferences valued as one sign of shared agency. In a telling comment on the shift in authority represented by many groups coming together, Addams's memoir asserted that the Coffee House "performed a mission of its own," becoming "a social center" for the settlement and the larger community. ${ }^{54}$ So popular was the Coffee House, in fact, its original space had to be expanded to accommodate its burgeoning clientele. The Hull-House archives contain many photographs and drawings of the space as it grew and changed.

\section{Foodways and Power Differentials}

However compelling recurring descriptions of the inclusive Coffee House patronage may be, we should not lose sight of the power differentials that remained in force within the settlement's management of foodways, even in this vibrant intercultural space. In Addams's own day, these power differences resided in part within the economic structures that enabled the settlement as a whole to thrive, both materially and programmatically. Like the Labor Museum, the Coffee House would not have been possible without resources that Addams, working from her position of economic privilege, could marshal. Thus, Lisa Lee has explained, “Addams borrowed money from Mary Rozet Smith's father to start the Hull-House Coffee House, which was established in July 1, 1893" and overseen by "Julia Lathrop, a Hull-House resident." Regarding Lathrop as the original Coffee House manager, Lee has offered up an appealing portrait of "one of the foremost advocates for the health and well-being of mothers and children," who was "also known as a fabulous cook" making "delicious omelets and brown butter oysters at midnight for the other residents." ${ }^{55}$ On one hand, Lee saluted Lathrop's administrative leadership. On the other, Lee served up a vivid picture of a domesticated chef, creator of tasty late-night meals beloved by the settlement's residents. ${ }^{56}$

Submerged within this appealing anecdote, however, is another vital point. If Lathrop had full access to the Coffee House kitchen at midnight, the same could not be said for Hull-House's neighbors. Being a resident, especially one of Addams's close friends, had its privileges. And among those privileges, as a flip side to cooking a late-night meal in the Coffee House kitchen, was having earlier evening meals prepared for and served to residents nightly in the settlement dining hall. While the public dining hall of the Coffee House transformed over time into a space that recognized the multiple meanings of food to neighbors, Hull-House remained a house with private spaces only accessible by residents. A list of those gathering together to share news of their busy daytime work reads like a "who's who" of the Progressive Era, with luminaries like John Dewey and Upton Sinclair joining table talk with Hull-House women Florence Kelley, Alice Hamilton, and Lathrop, as well as an ever-expanding array of internationally renowned guests. Polacheck's commentary, at the start of this article, on being breathlessly honored to join Addams's own table, reflects her 
awareness of this dining table's star power - a social hierarchy that she, for one, is disinclined to critique. To their credit, the curators of the JAHHM took on this power differential in an award-winning exhibit managed by Heather Radke. "Unfinished Business: 21st-Century Home Economics" spotlighted Hull-House women influential in the domestic science movement, including Helen Stuart Campbell and Caroline Hunt. The exhibit also celebrated such multidimensional settlement foodways leaders as Ida Foster Cronk, described on an exhibit label as "Hull-House Coffee Shop Manager // Restauranteur // Kitchen Design Innovator." Yet another goal of this project involved honoring housekeeper Mary Keyser, who, as Radke indicated, "shouldered the work of domestic life so that other residents could do a wide range of work that made Hull-House a crucial space for democracy." ${ }^{57}$ It is important to remember that each occasion of commensality is perhaps built on the labor of individuals who do not share the same access to the table.

Addams herself had made at least one attempt to undo social distinctions associated with who made versus who was served food intended for the larger community of Hull-House. As she recounts in an oft-cited episode of her Twenty Years memoir, she took a pilgrimage-like journey to Russia to meet Tolstoy, whom she admired as much for his humanitarian kinship with local peasants as for his authorship. Seeing him work in the fields and eat "only porridge and black bread" along with peasants with whom he had worked, Addams returned to Chicago determined to enact the settlement's bread-making task literally. Once back at Hull-House, however, Addams realized that "the whole scheme seemed to me as utterly preposterous as it doubtless was. The half dozen people invariably waiting to see me after breakfast, the piles of letters to be opened and answered, the demand of actual and pressing human wants - were these all to be pushed aside and asked to wait while I saved my soul by two hours' work at baking bread?" 58 While Addams recognized that the unearned privileges of class and whiteness may have created inequalities between herself and the neighbors of Hull-House, taking on the symbolic labor of breaking bread was more effective at self-aggrandizing than alleviating any material burden of "actual and pressing human wants." Addams concludes that while the labor of bread baking may be duplicated by many, her work as settlement house leader could not. After all, labor saving and labor sharing were central tenets of the home economics movement - including the NEK and the Coffee House. "Lighting one fire instead of fifty," a familiar slogan of domestic science, necessarily freed 49 women to do some other kind of valuable work rather than tend the fire. ${ }^{59}$

\section{Shared Foodways as Social Equalizers}

Even if some might fault Addams for giving up on her literal bread making, Polacheck's memoir shows that immigrant neighbors could still find signs of egalitarian foodways within an overarching culture of communal welcome at the settlement. As noted earlier, Polacheck's own sustained connection to Hull- 


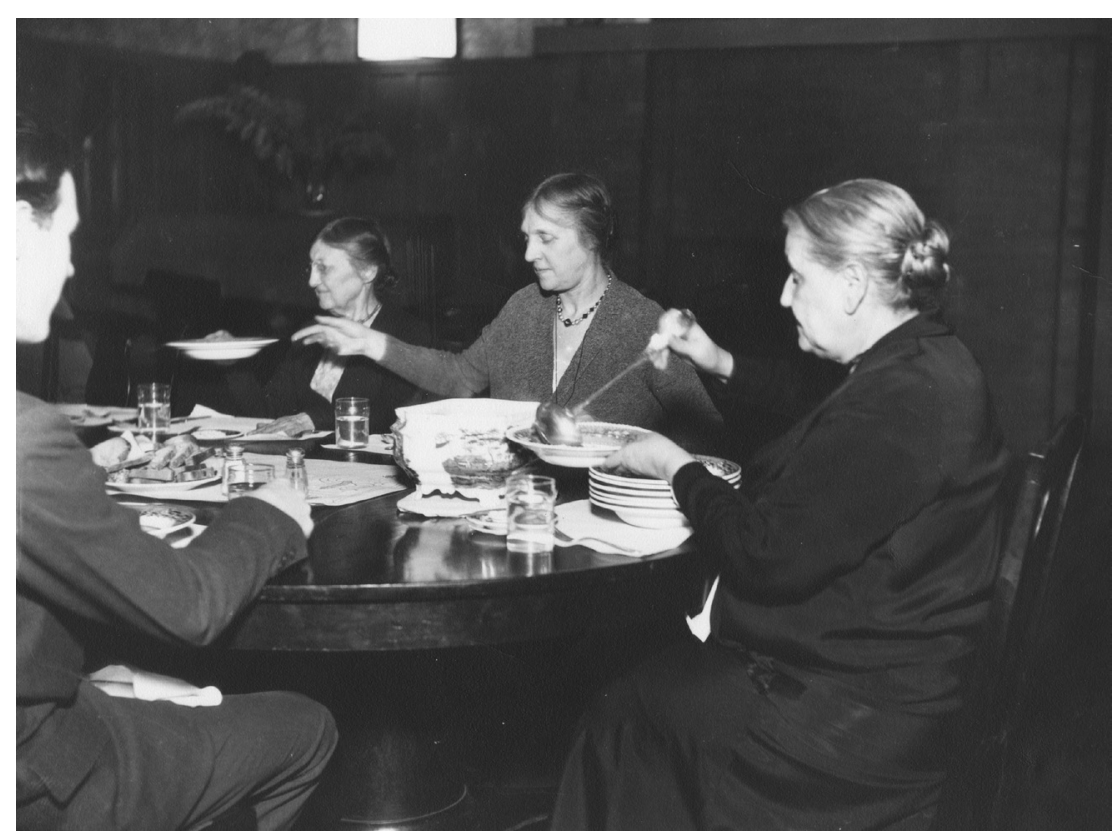

Figure 6: Addams serving soup to Hull-House Residents. The Hull-House dining room table served many great luminaries of the Progressive Era, but the table - and the activities of such luminaries - were made possible by the often-invisible service of support staff. Citation: Hull-House Residents, undated. Hull-House Photograph Collection, JAMC_0000_0310_3691, Special Collections and University Archives, University of Illinois at Chicago.

House developed starting in 1900 through the Labor Museum and the Coffee House. Explaining that her choice to "walk over to Hull-House three blocks from where I lived" on Halsted wound up marking "the beginning of a new life for me," she characterized her initial conversation with Jane Addams as representative of the settlement leader's welcoming approach. When Addams, greeting her in the reception room, asked if she would like "to join a club or a class," this young neighbor confessed to uncertainty. So Addams escorted the then-hesitant visitor - who had spent all day in factory work - to the Labor Museum. After introducing Polacheck to museum director Mary Hill, Addams left the two to become acquainted. Not long afterwards, Polacheck became one of the docents. ${ }^{60}$

Collaboration in the museum seeded a friendship between Hill and Polacheck - one reinforced, according to I Came a Stranger, when "Miss Hill" issued the first invitation her protégée had ever received "to dinner . . outside of my home." Recalling her hesitation, Polacheck confessed that this muchwelcome moment was also a trial, one she struggled to explain to her mentor: 
" "Oh, I want to come, . . . but I have never eaten anyplace else and maybe I would not know how to act." Hill's reassuring response ("'You don't have to act. ... Just eat the way you eat at home."') led to Polacheck's appearing at "the appointed evening," dressed in "a clean cotton dress and my hair in perfect order." As they sat together "at a small, black, square table" in the Coffee House, Polacheck couldn't help noticing that the table "had no tablecloth," whereas her "mother always used a tablecloth when we had company." If the Coffee House setting was surprising in its informality, the menu turned out to be a bit stress inducing. She hesitated to accept Mary Hill's offer of "a lamb chop," because the meat might not be kosher. "So," said Polacheck, looking back, "I asked her if I could have eggs." Describing the "very nice mushroom omelet" they both then ordered, this story of Polacheck's first experience dining out-made possible, after all, by Hull-House - presented one more admission of concern: not yet knowing the English word for "mushrooms," her proposal of an egg dish inadvertently generated a new worry, that this then-mysterious ingredient also might not be kosher. She boldly ate it anyway. ${ }^{61}$

In this remembrance of cross-class, cross-ethnic connections over a Coffee House meal, Polacheck blended nostalgia similar to her portrait of the dining table at the fortieth-anniversary reunion meal with a more candid admission of the power differentials that made Hill's invitation both appealing and challenging. Meanwhile, by also referencing Hill's sensitive efforts to address her young guest's concerns, Polacheck's anecdote exemplified how Hull-House community members from different backgrounds could strive, together, to accommodate each other when seeking solidarity through shared foodways. In that vein, Gabaccia argues that "crossing cultural boundaries" by eating can enable an "exploration and accommodation" of the Other. And though this inevitably leads to some loss of one's original identity, the mixing of diverse foodways can be a creative force, encouraging innovation and preservation at the same time. ${ }^{62}$

Overall, while it's important not to overcredit Addams and her colleagues when revisiting the archive of Hull-House foodways, it's equally essential to allow a chronicle like Polacheck's - especially when read alongside Addams's own memoir - to give the settlement its due, as in the example of the young immigrant's first Coffee House meal. And lest we assume that her experiences of food culture there to be unique, she weaves into her memoir several striking accounts of how the expansive hospitality represented in the Coffee House was extended to others as well, in line with the settlement's core values.

One of these episodes indirectly claims, for Addams, a strong awareness of class hierarchies and a determination to resist them through sociable food practice:

I remember one day the daughter of a wealthy family had come to Hull-House to help in the reception room, and an old shabby woman came in and asked for Miss Addams. Looking down at the poor woman, the young lady started to tell 


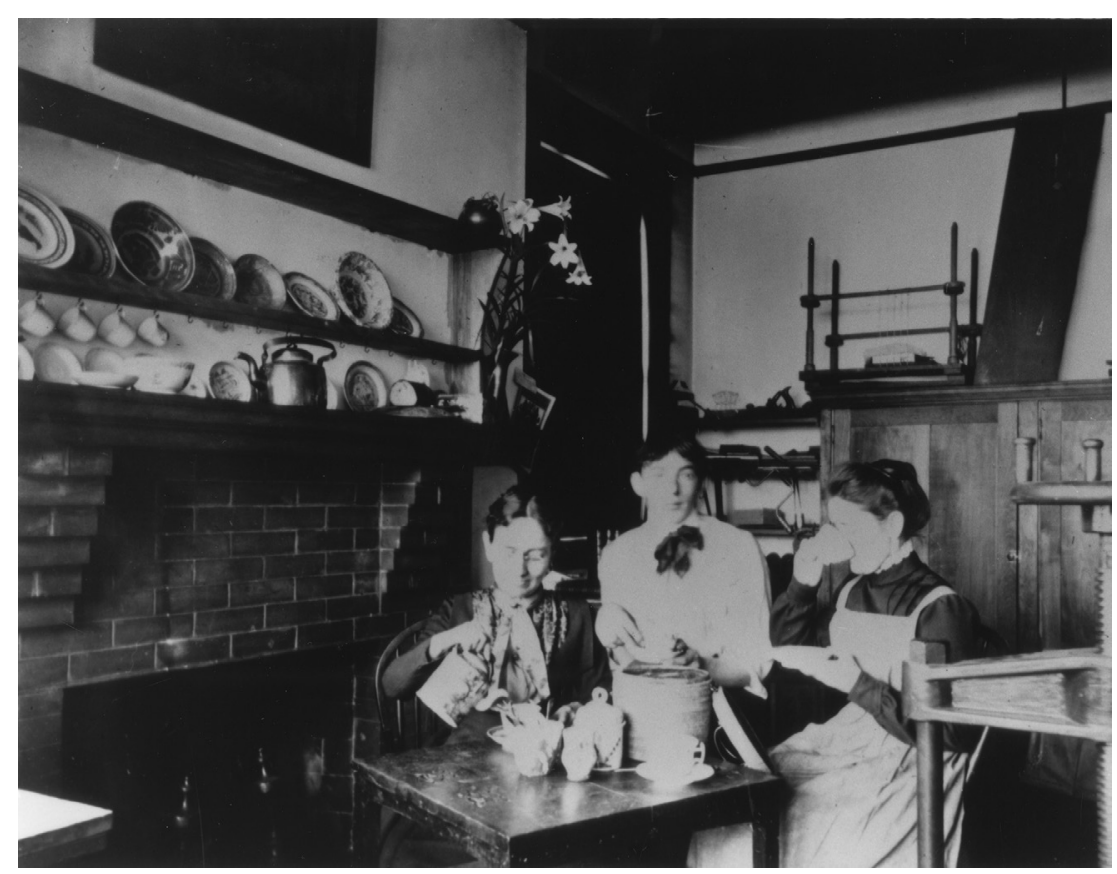

Figure 7: Ellen Gates Starr, her bookbinding pupil Peter Verburg, and Jane Addams having tea in the bookbindery in the Hull-House Labor Museum. The serving and sharing of tea can be read as an act of cross-class and cross-cultural solidarity. Citation: Hull House-Personalities-Starr, Ellen Gates, undated. Hull-House Photograph Collection, Special Collections and University Archives, University of Illinois at Chicago.

her that Miss Addams was busy and could not be disturbed, just as Miss Addams was coming down the stairs. She quickly told the young lady that perhaps she had better go home. Then she took the old woman by the arm and said she was just going to have a cup of tea and would she join her. ${ }^{63}$

Polacheck's portrait of Addams here emerges through veneration of the contrast between the settlement leader's hospitable stance and the unenlightened behavior of the "daughter of a wealthy family." Addams's offer of tea underscores this contrast while also asserting the potential for shared foodways to reach across - even if not eradicate - class lines. Figure 7 below shows Addams and Starr sharing tea with Peter Verburg, a student and neighbor, crossing lines of gender, as well, in this purposeful act. Though some dining spaces of Hull-House remained private and accessible only to the privileged residents, the public spaces created by club activities facilitated purposeful exchanges of 
food and drink that brought residents and neighbors into social interactions that elided differences in class, ethnicity, and gender, even if only temporarily.

Hilda Polacheck would return to this symbol of social tea drinking as embodiment of the settlement's intercultural bridge building in a commentary on the Woman's Club's regular use of tea and cake. Polacheck emphasized to her readers that this club's membership included "most of the residents," a notable number of upper-class Chicago social leaders (like "Mrs. Joseph T. Bowen, who was perhaps the larger single contributor to Hull House"), as well as working-class neighbors like herself. Celebrating the range of ethnic as well as class diversity within the group, Polacheck also touted their use of collaborative foodways to bond, noting how the neighborhood's immigrant women, in particular, gained special solace from this ritual:

The Hull-House Woman's Club . . brought together women from all over the world. Once a week the women could leave their dreary homes and commune with other women and enjoy the hospitality of a cup of tea and a piece of cake. A cup of tea and a piece of cake may be trite things to most of us. But to sit down and have a cup of tea that you did not have to brew yourself and a piece of cake that you did not have to bake was an event in the lives of the women of South Halsted Street. ${ }^{64}$

In our own highly charged political moment, we find that engagement with the cultural resources in the archive of Hull-House food practices can be especially productive. As in Addams's day, we hear intense debates about the place of immigrants in our national community. If Addams's assumption, early in the settlement's history, that members of the dominant culture needed to save immigrants from themselves by promoting assimilation represented a less offensive stance than that of many nativist screeds of that time, she deserves even more credit for moving past her initial views. Her shift to a more collaborative stance that embraced inclusiveness over assimilation may never have fully achieved the idealized vision of reciprocal learning to which her soaring language repeatedly aspired. Yet, the settlement did embrace foodways to celebrate diversity. In establishing and nurturing shared spaces and practices for cross-cultural food practices like the Coffee House and the Woman's Club, Hull-House developed a model for intercultural connections adaptable to today's challenging context. We would do well to resist assumptions that the presence of food alone creates community. The occasions of cross-cultural eating described here served not merely as symbols of solidarity but also as opportunities for dialogue and collaboration on solutions to shared problems. Instead, we should take the learning legacies of Hull-House to heart, recognizing that all food encounters are imbricated in a complex web of identities and that careful attention to these complexities is essential to fostering reciprocal communities of shared authority. 


\section{Sara Robbins and Carrie Helms Tippen}

\section{Notes}

1. Hilda Satt Polacheck, I Came a Stranger: The Story of a Hull-House Girl, ed. Dena J. Polacheck Epstein (Urbana: University of Illinois Press, 1989), 167.

2. Polacheck, I Came, 167. Polacheck began her autobiography in 1953. When she died in 1967, the narrative remained unpublished. Her daughter and eventual editor Dena Epstein reports that publishers had "rejected the manuscript" with comments such as "Who wants to read about an obscure woman like you?"” (I Came, "Afterword," 179). Epstein synthesized the many drafts her mother had produced over the years (I Came, 180), ensuring that "the only known description of Hull-House written by a woman from the neighborhood" reached publication (I Came, 179).

3. See Sarah Robbins, "Rereading the History of Nineteenth-Century Women's Higher Education: A Reexamination of Jane Addams' Rockford Education as Preparation for her Twenty Years at Hull-House Teaching," Journal of the Midwest History of Education Society, 21 (1994): 27-46.

4. Erik Schneiderhan provides a helpful survey of publications on Addams and the settlement as passing through multiple stages, beginning with treatments casting her as a heroine but then moving into a persistent phase of critique of Hull-House and its leader as patronizing and committed to race-based and class-distinctive hierarchies. See Erik Schneiderhan, "Pragmatism and Empirical Sociology: The Case of Jane Addams and Hull-House, 1889-1895," Theory and Society 40 (2011): 589-617.

5. Appreciative studies of Addams's civic leadership and democratic vision include both biographies and analyses of Hull-House as a site of (proto-)feminist collaboration. See Jean Bethke Elshtain, Jane Addams and the Dream of American Democracy (New York: Basic Books, 2002); Louise W. Knight, Citizen: Jane Addams and the Struggle for Democracy (Chicago: University of Chicago Press, 2006); Victoria Bissell Brown, The Education of Jane Addams (Philadelphia: University of Pennsylvania Press, 2003); and Maurice Hamington, Embodied Care: Jane Addams, Maurice Merleau-Ponty, and Feminist Ethics (Urbana: University of Illinois Press, 2004).

6. Lisa Heldke, Exotic Appetites: Ruminations of a Food Adventurer (New York, NY: Routledge, 2003), 177. James Watson and Melissa Caldwell similarly remind us in The Cultural Politics of Food Eating (Malden, MA: Blackwell Publishing, 2005), 1, that food practices operate "in a complex field of relationships, expectations, and choices that are contested, negotiated, and often unequal."

7. Josée Johnston and Shyon Baumann, Foodies: Democracy and Distinction in the Gourmet Foodscape (New York, NY: Routledge, 2010), 4.

8. Alice P. Julier, Eating Together: Food, Friendship, and Inequality (Chicago: University of Illinois Press, 2013), 5.

9. E.N. Anderson, Everyone Eats: Understanding Food and Culture (New York: New York University Press, 2005), 125.

10. Hull-House Bulletin, 1.2 (February 1896): 2. Hull House Collection, Special Collections and University Archives, University of Illinois at Chicago. Further citations to the scrapbooks, as well as to Hull-House bulletins and yearbooks, reference the same collection, as we will note via an HHC designation.

11. Michel de Certeau, The Practice of Everyday Life, trans. y Steven Rendall. (Berkeley: University of California Press, 1988), ix, xxii, 40, 115, 176. For a framework envisioning progression from studying historical cases of intercultural exchange to doing civic engagement work today, see Sarah Ruffing Robbins, Learning Legacies: Archive to Action through Women's Cross-Cultural Teaching (Ann Arbor: University of Michigan Press, 2017). The chapter on Hull-House's learning legacies includes analyses of collaborative practices carried out among women associated with the settlement in Addams's day and the influence of that legacy on cultural stewards, such as a writing collaborative associated with UIC's English Department and the staff at the Jane Addams Hull House Museum.

12. Barbara Sicherman underscores a parallel tendency in treatments of Hull-House literacy programs to overemphasize the early book clubs sponsored by Ellen Gates Starr and Jane Addams as signs of the settlement's imposing white canonical material on immigrant learners. See "Hull-House as a Cultural Space," Well-Read Lives: How Books Inspired a Generation of American Women (Chapel Hill: University of North Carolina Press, 2010), 165-92. As a counterpoint to oversimplified critiques, we can invoke Polacheck, who relishes remembering her own studies of Shakespeare plays with Poetry Magazine editor Harriet Monroe (I Came, 76).

13. Jane Addams, "The Objective Value of a Social Settlement," in Philanthropy and Social Progress, ed. Professor Henry C. Addams (New York: Thomas Y Crowell, 1893), 33. Addams would later incorporate updated versions of her two essays into her bestselling account of the settlement, Twenty Years at Hull-House, with autobiographical notes (New York: Macmillan, 1910).

14. Polacheck, I Came, 52, 67.

15. Though gendered analyses now often invoke the concept of "intersectionality" to highlight the complex interplay among the multiple facets of identity and associated differing life experiences that any one woman would have, we avoid applying a term here that, on the one hand, would not have been available to Addams and her colleagues in her day and that, on the other, 
has had a special role to play in scholarly work focused on black/womanist experiences versus in broader multiethnic and multiracial settings like Hull-House. See more from Kimberlé Crenshaw, "Mapping the Margins: Intersectionality, Identity, and Violence Against Women of Color," Stanford Law Review, 43, no. 6 (1991): 1241-1300, and D. Carbado, K. Crenshaw, V. Mays, and B. Tomlinson, "INTERSECTIONALITY: Mapping the Movements of a Theory," Du Bois Review: Social Science Research on Race, 10, no. 2 (2013): 303-312.

16. On the role that Addams's decades-long friendship with Henrietta Barnett played in both women's settlement leadership, see Sarah Ruffing Robbins, "Sustaining Gendered Philanthropy through Transatlantic Friendship: Jane Addams, Henrietta Barnett and Writing for Reciprocal Mentoring," in Poverty, Giving, and the Culture of Altruism: Transatlantic Philanthropy 1850-1920, ed. Frank Christianson and Leslee Thorne-Murphy (Bloomington: Indiana University Press, 2017), 211-35.

17. Addams, Twenty Years, 292.

18. For examples, see in Twenty Years, 21, 103, 163, 191, 253. Bread is the organizing and recurring metaphor for Addams's Peace and Bread in Time of War (New York: Macmillan, 1922).

19. Twenty Years, 57.

20. Catharine Beecher and Harriet Beecher Stowe argued in The American Woman's Home: Or, Principles of Domestic Science (New York: J.B. Ford and Company, 1869), 13, that treating domestic work as a science and teaching it through the institutions of power (education and publishing) would "render each department of woman's true profession as much desired and respected as are the most honored professions of men." However, as Laura Schenone points out in A Thousand Years Over a Hot Stove (New York: W.W. Norton, 2003), 123, Beecher "never had a home of her own and probably did not cook much herself." Like Addams and Hull-House residents, Beecher and Stowe also depended on working-class housekeepers to free them up for writing and other professional work.

21. For discussion of how Stowe incorporated the ideology of home economics into a number of her post-Civil War novels, see Lisa Watt Macfarlane, "The New England Kitchen Goes Uptown: Domestic Displacements in Harriet Beecher Stowe's New York," The New England Quarterly, 64.2 (June 1991): 272-91.

22. Lisa Yun Lee, "Hungry for Peace: Jane Addams and the Hull-House Museum's Contemporary Struggle for Food Justice." Peace \& Change, 36.1 (January 2011): 69.

23. Twenty Years, 130. Also known as the "Rumford Kitchen," the NEK was featured at the 1893 World's Columbian Exhibition in Chicago, but the residents of Hull-House had already been familiar with Richards and Abel's project for a few years through the community of home economics and Richards' visits to Hull-House. The representative sent to Boston was Annie Lathrop. See Diane Dillon, "Hull-House Experiments with the New England Kitchen and Develops Programs in Homemaking," Urban Experience in Chicago: Hull-House and Its Neighborhoods, 1889-1963, http://hullhouse.uic.edu/hull/urbanexp/main.cgi?file=new/show_doc.ptt\&doc=10\&chap=35

24. Lee, "Hungry," 70.

25. Twenty Years, 129.

26. Scrapbook Volume 1: clippings 1889-1894 (August 24, 1893): 58. HHC.

27. Scrapbook Volume 1: clippings 1889-1894 (August 24, 1893): 58. HHC.

28. See Mary Abel Hinman and Ellen H. Richards. The Story of the New England Kitchen: A Study in Social Economics (Boston: Rockwell and Churchill, 1893). See also Dolores Hayden, The Grand Domestic Revolution: A History of Feminist Designs for American Homes, Neighborhoods and Cities (Boston, MA: The MIT Press, 1982), 148.

29. Twenty Years, 130.

30. Hayden, Grand Domestic Revolution, 151, 153. Illustrating the ongoing focus on domestic science at the settlement, multiple issues of the Hull-House Bulletin from 1896 show that a twelve-week course on "Chemistry of Food" was being regularly offered. Hull-House Bulletin 1.4 (April 1896): 2. HHC.

31. See Heldke, "Exotic Appetites," 2003; Johnston and Baumann, Foodies, 2010; Julier, Eating Together, 2013; and Anderson, Everyone Eats, 2005. In "Toward a Psychosociology of Contemporary Food Consumption," Roland Barthes stresses that foodways represent a building block of culture: "as soon as the basic needs [for nutrition] are satisfied" in a civilization, food becomes more important as a "protocol," "sign," "situation," or "institution" than as mere caloric intake. In Food and Culture: A Reader, ed. Carole Counihan and Penny Van Esterik (New York: Routledge, 2013), 24.

32. Schenone, Hot Stove, 113.

33. Elizabeth S.D. Engelhardt. A Mess of Greens: Southern Gender \& Southern Food. (Athens: University of Georgia Press, 2011), 55.

34. Addams subscribed to a clipping service that sent her copies of periodical stories about Hull-House. Her margin notes in the scrapbooks where these accounts are pasted only occasionally provide citations. This scrapbook clipping, dated August 24, 1893, comes from a newspaper article entitled "Hull House Kitchen Opened." Scrapbook Volume 1: clippings 1889-1894: 58. HHC.

35. Twenty Years, 131. 


\section{Sara Robbins and Carrie Helms Tippen}

36. This quotation comes from an unsigned "Coffee House" article, Hull-House Yearbook, 1906-07, 40. Accounts giving virtually the same information, often with the same wording (since yearbooks often reused past typesetting) include these: Yearbook 1910, 43; Yearbook 1913, 46; Yearbook, 1916, 50. HHC.

37. Twenty Years, 132.

38. "Plans for the Poor." Scrapbook Volume 1: clippings 1889-1894, 58. HHC. An article pasted in Addams's scrapbook of clippings, "What Hull House Really Is," praises the settlement in such terms: "It's . . . going to leaven the whole lump of the Nineteenth Ward . . . . [T] he father has a hot lunch of soup and rolls delivered to the factory at noon for 10 cents, the older girls are being fitted for domestic service in the cooking school. ... When the tired mother comes back from her scrubbing she buys a pot of beans or a quart of Irish stew and good bread at the New England kitchen and takes it home piping hot. Her husband brings a bushel of coal from the Hull House cooperative yard." Scrapbook Vol 3: clippings and publications, 1895-1897 (April 28, 1895), 3. HHC.

39. "Ice and Milk," Hull-House Bulletin 6.1 (Autumn 1904): 20. HHC.

40. Donna R. Gabaccia, We Are What We Eat: Ethnic Food and the Making of Americans (Cambridge: Harvard University Press, 1998), 37, 40, 45, 48.

41. Polacheck, I Came, 61 .

42. Polacheck, 79-80.

43. Polacheck, 71.

44. Polacheck, 101 .

45. Lee, "Hungry," 68.

46. See Shannon Jackson, Lines of Activity: Performance, Historiography, Hull-House Domesticity (Ann Arbor: University of Michigan Press, 2001), 55-56.

47. Twenty Years, 453.

48. Bulletin, 1.1, 1. HHC.

49. Bulletin, 5.1, 11. HHC.

50. Bulletin, 6.1, 11; 6.2, 14-15; 7.1, 4. HHC.

51. Yearbook, 1916, 38. HHC.

52. Polacheck, I Came, 94-95.

53. Yearbook, 1906, 40-41. HHC.

54. Twenty Years, 132; see also Bulletin 4.4, 16. HHC.

55. Lee, "Hungry," 70-71. Mary Rozet Smith became one of Hull-House's major financial supporters. She was also Addams's life partner. Though early biographers hesitated to address their bond directly, another of Lisa Lee's contributions to the JAHHM was an exhibit inviting visitors to consider how best to convey the depth of their relationship. See Lisa Yun Lee, "Peering into the Bedroom: Restorative Justice at the Jane Addams Hull House Museum" in The Routledge Companion to Museum Ethics, ed. Janet Marstine (New York: Routledge, 2011), 174-87.

56. For Addams's own portrait of Lathrop (in My Friend, Julia Lathrop) as a shadow autobiography, see Chapter Three of Robbins, Learning Legacies, cited above.

57. Heather Radke, "Unfinished Business," Museum Magazine (May/June 2013): 86.

58. Twenty Years, 272, 276.

59. Lee, "Hungry," 71.

60. Polacheck, I Came, 63.

61. Ibid., 66.

62. Gabaccia, What We Eat, 225, 230.

63. I Came, 75.

64. Ibid., 100-101. 